\title{
Rudolf Bultmann se benadering tot die dag van die Here in 2 Petrus
}

\author{
Gert Malan \& Andries van Aarde \\ Departement Nuwe-Testamentiese Wetenskap (Afd A) \\ Universiteit van Pretoria
}

\begin{abstract}
Rudolf Bultmann's programme of demythologixing applied to the concept of the day of the Lord in 2 Peter

In order to grasp the meaning of the concept of the day of the Lord in 2 Peter for today 2 Peter is interpreted in terms of a specific historical. phase of eschatological development in the early church. Once this is done, the search for the meaning of such a concept for modern people is done by means of demythologization and existential interpretation.
\end{abstract}

\section{INLEMDNG}

Die dag van die Here word in 2 Petrus op 'n unieke manier beskryf. Nêrens anders in die $\mathrm{Ou}$ of Nuwe Testament word beskryf dat die hemel en die aarde deur vuur sal vergaan nie (Elliott 1982:155). In 'n ander bydrae het die skrywer gepoog om die betekenis van die betrokke konsep te verstaan aan die hand van die kennissosiologiese benadering (vgl Malan \& Van Aarde 1998:529). Hierdie studie poog om die saak vanuit Bultmann se ontmitologiseringsprogram te ondersoek. Hierdie benadering hou nie alleen rekening met die historiese gesitueerdheid van die dokument binne die ontwikkeling van die eskatologie in die vroeë kerk nie. Dit poog om deur ontmitologisering en eksistensiale interpretasie die dag van die Here vir moderne gelowiges meer verstaanbaar maak. Ten einde die konteks van die eskatologiese denke van die outeur te verstaan, is dit nodig om die ontwikkelingsgang van die eskatologie te begryp.

* Hierdie artikel is 'n verwerking van die resultate van die DD-proefskrif, "n Herwandering van Rudolf Bultmann se ontmitologiseringsprogram in die lig van die kennissosiologie: Die dag van die Here in 2 Petrus as voorbeeld'. Hierdie proefskrif is ingedien en anvar as deel van die vereistes vir die DDgrasd (1998), Departement Nuwe-Testamentiese Wetenskep, Falulteit Teologie (Afdeling A), Universiteit van Pretoria, onder leiding van prof dr A G van Aarde. 


\section{BULTMANN SE SIENING VAN DIE PLEK VAN DIE DAG VAN DIE HERE IN 2 PETRUS BINNE DIE HISTORIESE ONTWIKKELING VAN DIE ESKATOLOGIE}

Getrou aan sy histories-kritiese benadering herken Bultmann 'n ontwikkelingsgang in die teologiese denke binne die Nuwe Testament, soos wat die hoofstukindeling van sy Theologie des Neuen Testaments (1980) dan ook weerspieèl. Dieselfde ontwikkeling is derhalwe te bespeur wat betref die eskatologie as belangrike faset van teologiese denke. Eskatologiese denke is egter nie beperk tot die Bybel nie, en selfs buite-Bybelse eskatologie toon 'n historiese ontwikkeling. In hierde hoofstuk kom Bultmann se siening hieroor aan die orde, met die doel om die plek van die dag van die Here in 2 Petrus vas te stel. Daar word nie gepoog om 'n volledige bespreking te bied van elke stadium in die ontwikkeling van die eskatologie nie, maar slegs enkele basiese lyne word getrek. Sodoende kan Bultmann se siening van die ontwikkelingsgang van die eskatologie duidelik word vir 'n beter verstaan van sy siening oor die eskatologie van $2 \mathrm{Pe}$ trus, en spesifiek die dag van die Here as eskatologiese begrip.

\subsection{DIE OORSPRONG VAN ESKATOLOGIESE DENKE}

Bultmann (1975:23) definieer die begrip eskatologie nie maar net breedweg as die leer oor die laaste dinge nie, maar spesifiseer dit akkurater as die leer oor die gebeure waardeur ons bekende wêreld aan 'n bestemde einde sal kom. Mites oor die einde van die wêreld word onder 'n groot verskeidenheid volke aangetref. Dit word byvoorbeeld beskryf as die toekomstige einde van die wêreld as gevolg van 'n vernietiging deur water of vuur of ' $n$ ander katastrofe. Of hierdie mites almal hulle oorsprong het in dieselfde soort denke en of natuurlike katastrofes by voorwetenskaplike mense die indruk gelaat het van die einde van die wêreld, sal seker nie definitief vasgestel kan word nie.

Die eskatologie is 'n begrip wat handel oor die periodisiteit van die verloop van die historiese gebeure. Hierdie idee is gevorm deur die verloop van die wêreldgebeure te beskou na analogie van die jaarlikse periodisiteit van die natuur. Soos wat die seisoene van die jaar mekaar opvolg, so volg die periodes in die verloop van wêreldgebeure mekaar op, om die sogenaamde jaar van die wêreld of die groot wêreldjaar te vorm. Moontlik is hierdie esicatologiese denke sterk beïnvloed deur die astronomiese ontdekking dat die plek van die sonsopkoms van jaar tot jaar verander totdat die ekliptika verbygesteek is en die son weer terugkeer na die oorspronklike posisie. Wanneer 'n sodanige rondte voltooi sou word, sou dit beteken dat die groot wêreldjaar verby is. Net soos wat die een seisoen op die ander volg, so sou 'n nuwe wêreldjaar vorm en al die gebeure van die ou jaar sou weer herhaal. Die tydsverloop word beskou as siklies en nie as 'n konstante progressie nie (Bultmann 1975:23-24). 


\subsection{Eskatologiese denke in die Griekse filosofie}

Die idee van die terugkeer van alle dinge, wat uit die Oosterse astronomie ontwikkel het, is deur die Griekse filosofie verder ontwikkel, veral deur die Stoa. Hulle het geleer dat die wèreldeinde sal plaasvind deur 'n groot en vernietigende vuur wat die wêreld weer terug sal bring na Zeus, wat dit opnuut weer sal uitstraal as 'n nuwe wêreld. Alle tydperke en gebeure sal dan weer net so herhaal word (kyk Bultmann 1975:24).

Bultmann (1975:24-26) wys daarop dat die Griekse filosofie twee belangrike ontwikkelings in die eskatologiese denke gebring het, naamlik die rasionalisering en die historisering daarvan. Die kosmiese eskatologie is gerasionaliseer deur die invloed van die Griekse wetenskap. Die Stoisyne baseer hulle leer oor die vernietiging van die wêreld deur vuur op 'n teorie oor die essensie van die elemente waaruit die wêreld bestaan en die interaksie van daardie elemente. Die kosmiese mitologie is gehistoriseer deurdai die periodes van die wêreldjaar wat aanvanklik beskou is as 'n natuurlike opeenvolging, soos dié van die seisoene, later onderskei is deur dit te verbind het met die wisseling van menslike geslagte wat in die verskillende tydperke lewe. Hieruit ontwikkel dan die idee van degenerasie. Die permanente agteruitgang van die menslike geslag word dan aangedui deur dit in verband te bring met sekere metale wat in volgorde van afnemende waarde gerangskik word, naamlik goud, silwer, brons en yster. Nog groter belangrikheid moet geheg word aan 'n besondere vorm van historisering, naamlik die siening dat die ewige sikliese opeenvolging van wêreldjare vervang is met die idee van 'n nuwe begin aan die einde van die periodes hierbo genoem. Hierdie 'nuwe begin' lui 'n tydperk van oneindige welvaart in. Dit beteken dat die kosmiese wêreldjaar gereduseer is tot die geskiedenis van hierdie wêreld.

\subsection{Eskatologie in die Ou Testament}

Volgens Bultmann (1975:27) is daar buiten die boek Daniël nie in die Ou Testament sprake van eskatologie in die ware sin van die woord nie, naamlik van die einde van die wêreld en die daaropvolgende tydperk van verlossing nie. Dieselfde historisering van die eskatologie wat in die Griekse filosofie ontwikkel het, het reeds 'n bepaalde gang in die Iranse spekulasie gehad op grond van beinnloeding deur die Babiloniese godsdiens. Bultmann beskryf hierdie eskatologiese denke as eskatologie in die ware sin van die woord. Volgens hierdie denke sal die laaste dinge teen die einde van die bestaande wêreld plaasvind en die begin vorm van 'n nuwe en eindelose wêreld. Wat die eskatologie van die boek Daniël betref, bespeur Bultmann 'n soortgelyke historiserende tendens, maar as iets wat nie in die res van die Ou Testament na vore kom nie. Van deurslaggewende belang by die eskatologie in Daniël is dat die geheel van die menslike 
geskiedenis, afgesien van watter tydperk ook al, 'n eenheid vorm wat teenoor die tydperk van heil staan. Die eenheid van die tydperke in die geskiedenis lê daarin dat dit 'n tyd van boosheid is. So word daar twee tydperke in die wêreldgeskiedenis onderskei, die huidige bose aeon en die toekomstige aeon van heil.

Hierdie soort dualisme word nie in die res van die Ou Testament angetref nie, en is teenstrydig met die idee van God as Skepper. Bultmann (1975:28-29) erken dat OuTestamentiese profesieë voorspellings van heil en oordeel bevat, maar volgens hom is dit van toepassing op Israel of die volk se vyande. Die Goddelike oordeel waarvan die Ou Testament praat, is nie 'n oordeel oor die hele wêreld nie. Dit is 'n oordeel binne die geskiedenis self, alhoewel hierdie oordeel uitgebeeld word in mitologiese begrippe, soos kosmiese katastrofes, aardbewings, en vernietigende vuur. Hierdie begrippe is egter volgens Bultmann omamenteel aangewend en getuig inderdaad van die historisering van die kosmologie. Die beskouing van God as die Skepper het egter verhoed dat die idee van 'n sikliese beweging van wêreldtydperke deur Israel aanvaar is. Die mitologiese beeldspraak is egter tot 'n mate oorgeneem. Hierdie beeldspraak word onder andere gebruik in profetiese uitsprake oor die rampe wat ' $n$ verandering in Israel se lotgevalle voorafgaan, rampe wat later in die apokaliptiese literatuur beskryf word as tekens van die komende einde, as geboortepyne wat die koms van die Messias voorafgaan. Wat die profetiese uitsprake betref, is daar duidelik van historisering sprake. Die tydperk van rampe is 'n tydperk van oorlog wat Israel moet ondergaan, en dien ook as 'n straf vir die sondige volk. Net so is beeldspraak oor die tydperke van heil moontlik beinvloed deur die mitologiese idee van die terugkeer van die goue era, byvoorbeeld die beelde oor die vrede tussen mense en diere, die verandering van die woestyn in 'n paradys, sprake van die nuwe hemel en die nuwe aarde. Hierdie beelde is egter almal gehistoriseer, want hulle beskryf die welvaart van die volk Israel. Spesifiek kon die Messiaanse verwagting volgens Bultmann gegrond wees in die kosmiese mitologie, waarvolgens elke tydperk in die wêreldjaar regeer word deur 'n nuwe heerser. Ook hierdie hoop is duidelik gehistoriseer, aangesien die heerser wat verwag word vir die tyd van heil, 'n koning uit die huis van Dawid sou wees.

\subsection{Die eskatologie van die laat-Jodedom}

Die eskatologie van die laat-Jodedom staan bekend as apokaliptiese eskatologie en is sterk beinvloed deur Babiloniese en Iranse kosmiese eskatologie en mitologie (kyk Bultmann 1956:82). Dit het 'n wêreldbeeld tot gevolg gehad wat ingeklee is volgens die pessimistiese dualisme, maar op so 'n manier dat die leer oor die skepping nie prysgegee is nie. Hierdie wêreld, wat die toneel is van soveel lyding, siekte en dood, sonde en geweld, is die woonplek van die bose geeste met Satan as hulle hoof. Hulle staan 
die heerskappy van God teen; die magte van die duisternis voer 'n stryd teen die magte van die lig. Bevryding van die magte van die duistemis is moontlik deur die deelname aan sakramente asook deur middel van asketisme wat die siel verhef tot die sfeer van die lig, waarheen dit ook na die dood sal keer.

Deurdat die kosmologie in die latere Jodedom gehistoriseer is, is die lotsbestemming van die mensdom vervang met dié van die hele wêreld. Goddelike eindoordeel sou dan 'n einde aan die wêreld maak. Die idee van die twee aeone vervang die idee van sikliese periodes, en daarmee word 'n eskatologie in die ware sin daargestel. Aan die ander kant word die geskiedenis nou verstaan vanuit die hoek van die eskatologie. Dit dui 'n beslissende verandering vanaf die Ou-Testamentiese benadering aan. Die eindoordeel is nie meer gesien as 'n historiese gebeure nie, maar as ' $n$ bonatuurlike gebeure wat as ' $n$ kosmiese katastrofe sal realiseer. Die kosmiese beelde wat maar net ornamenteel was in die Ou-Testamentiese profesieë, word nou op sigself belangrik. Alle tekens van degenerasie wat voorheen gesien is as tekens van die laaste wêreldperiode, is nou gesien as tekens van die definitiewe einde van die wêreld. Die apokaliptiese literatuur verwag dan ook sulke tekens en beskou skrikwekkende gebeure in die natuur, asook oorloë, hongersnood en epidemies, as tekens van die einde wat ook bekend staan as die geboortepyne wat die koms van die Messias voorafgaan. Dit sal kulmineer in die koms van die Antichris. Laasgenoemde was oorspronklik 'n mitologiese figuur, die draak wat chaos verpersoonlik, maar is later as pseudo-profeet of pseudo-Messias, koning of Romeinse keiser geinterpreteer. Die verandering kom wanneer God of God se verteenwoordiger, die Messias of die Mens (Seun van die Mens) verskyn. Die persoon van die Verlosser is nou ook gemitologiseer deurdat die figuur van die Dawidieso koning nou vervang is met die mitologiese figuur van die Mens wat op die wolke sal kom. Dan sal die opstanding van die dooies ('n gedagte wat tot dusver vreemd aan die $\mathrm{Ou}$ Testament was) en die laaste oordeel plaasvind. Dit sal 'n forensiese daad wees, 'n oordeel oor die ganse wêreld, in die lig waarvan elkeen rekenskap sal moet gee van sy of haar dade (kyk Bultmann 1975:29-30).

Hierdie gedagtegang is die gevolg van Iranse invloed. Die lot van die goddelose is vernietiging of ewige pyniging in die vlamme van die hel. Hierdie gedagte is ook vreemd aan die Ou Testament, en is eers later oorgeneem. Die benaming Gehenna is vir die hel gebruik, 'n verwysing na die Dal van Hinnom waar kinders vroeër aan Moloch geoffer is. Vir die regverdiges wag daar die ewige lewe, waar hulle na die opstanding verander sal word tot stralende glorie en soos die engele beklee sal word in koninklike klere en krone (kyk Bultmann 1956:83-86).

In die laat-Joodse apokaliptiese eskatologie word die kosmologie en die geskiedsbeskouing gekombineer, maar op só 'n manier dat die kosmologie die botoon 
voer. Die einde van die geskiedenis hoort nie meer tot die geskiedienis self nie. Daarom kan dit ook nie meer die doel van die geskiedenis genoem word waxineen die geskiedenis stapsgewys beweeg nie. Die einde is nie die voltooiing van die geskiedenis nie, maar juis die afbreek daarvan, as 't ware die sterwe van hierdie wêrold weens die ouderdom daarvan. Dit ou wêreld sal vervang word deur 'n nuwe skepping, en daar is geen kontinuiteit tussen die twee aeone nie. Selfs die herinneringe aan die verlede sal verdwyn, en daarmee saam sal die geskiedenis verdwyn. In die nuwe aeon sal alle ydelheid tot niet wees, en sal daar nie meer 'n begrip van tydsverloop, soos dae, maande en jare, wees nie. 'n Verdere verkil tussen die Ou-Testamentiese verwagting en die apokaliptiese verwagting lê op die terrein van die verlossing en die verantwoordelikheid van die enkeling in hierdie verband. In die Ou-Testamentiese verwagting beteken verlossing die heil van die ganse volk. Daarom val die verantwoordelikheid van die enkeling saam met die verantwoordelikheid van die volk. In die apokaliptiek is enkelinge net vir hulleself verantwoordelik, omdat die einde tegelyk oordeel en heil bring en die enkelinge se toekoms bepaal sal word volgens hulle werke. Hierdie oordeel is dan 'n oordeel oor die hele wêreld. Die heil ter sprake is inderdaad ook die heil van die gemeenskap, maar die gemeenskap is 'n gemeenskap van die uitverkorenes, die heiliges, en nie van volke of nasies nie, maar van enkelinge (kyk Bultmann 1975:3031).

\subsection{Jesus se eskatologiese prediking}

In die Nuwe Testament word beide die Ou-Testamentiese en die apokaliptiese sienings aangetref. Vandag word allerweë anvaar dat die koninkryk van God wat Jesus aangekondig het, die eskatologiese heerskappy was. Die enigste verskilpunt is vir Bultmann (1975:32) die vraag of Jesus gedink het dat die koninkryk imminent was, en reeds met sy eksorsismes begin aanbreek het, en of Hy gedink het dat dit reeds in sy persoon aanwesig was (huidig bekend as gerealiseerde eskatologie). Hieraan verbonde is die vraag na wat Hy oor sy eie persoon gedink het. Wat wel algemeen aanvaar word, is dat Jesus sy tyd verstaan het as 'n tyd van beslissing, en dat mense se gesindheid jeens Hom en sy boodskap, vir hulle van deurslaggewende beleng was.

Volgens Bultmann is die dominante konsep in die boodskap van Jesus die koninkryk van God. Vir hom is dit die hart van Jesus se prediking. Die negentiende-eeuse eksegese en teologie het hierdie koninkryk van God verstaan as 'n geestelike gemeenskap bestaande uit mense wat saamgebind word deur gemeenskaplike gehoorsaamheid an God. Deur hierdie gehoorsaamheid word dan gepoog om die sfeer van God se heerskappy in die wêreld te vergroot. So het hulle as 't ware gepoog om die koninkryk van God uit te bou as 'n geestelike ryk wat aktief en effektief binne hierdie wêreld 
funksioneer en binne die geskiedenis van hierdie wêreld ontvou. Hiermee stem Bultmann nie saam nie en skaar hom by Johannes Weiss se eksegese, soos vervat in sy 1892 publikasie, Die Predigt Jesu vom Reich Gottes. Vir Bultmann (1958a:11-12) het Weiss voldoende aangetoon dat die koninkryk van God nie imminent in die wêreld en as deel van die wêreldgeskiedenis groei nie, maar 'n eskatologiese begrip is wat die historiese orde transendeer. Dit kom nie tot stand deur die morele prestasies van mense nie, maar slegs deur die bonatuurlike handeling van God. God sal 'n onverwagse einde aan die wêreld en die geskiedenis maak en Hy sal 'n nuwe wêreld bring, 'n wêreld van ewige geluksaligheid.

Die betekenis van hierdie eskatologiese begrip is die heerskappy van God wat die huidige gang van hierdie wêreld sal vernietig, asook al die anti-Goddelike, Sataniese magte waaronder die huidige wêreld kreun. Sodoende sal daar 'n einde kom aan alle pyn en lyding, en breek die verlossing vir die volk van God aan waarvan die profete getuig het. Die koms van God se koninkryk is 'n wonderbare gebeure wat deur God alleen teweeggebring word sonder die hulp van mense (kyk Bultmann 1980:3).

Hierdie beskouing oor die koninkryk van God is volgens Bultmann (1958a:12) nie 'n uitvinding van Jesus nie. Dit was 'n begrip wat bekend was in sekere na-eksiliese Israelitiese kringe wat die einde van die wêreld verwag het. Sy boodskap hou verband met die verwagting wat in die apokaliptiese literatuur gedokumenteer is (kyk Bultmann 1980:3-4). Hiervan is die boek Daniël die vroegste wat behoue gebly het. Die ooreenkoms tussen Jesus se boodskap en die apokaliptiek is dat verlossing teweeggebring sal word deur ' $n$ kosmiese katastrofe en nie deur die wonderbare verandering van politieke en sosiale omstandighede in die geskiedenis van die wêreld nie. Die vooronderstellings is die pessimistiese dualistiese wêreldbeskouing van die Sataniese verderwing van die wêreld met die gevolglike verdeling van die tyd in twee aeone, die einde van die ou aeon en die aanbreek van die nuwe. Dit sal plaasvind op die dag deur God bepaal en dan sal God of God se verteenwoordiger, die Seun van die Mens, oor die lewendes en die dooies oordeel volgens hulle dade. Verlossing van die gelowiges sal nie bestaan uit nasionale voorspoed of eer nie, maar in die geluk van die paradys. Die verskil tussen Jesus se boodskap en die apokaliptiek is dat Jesus nie gedetailleerde beelde gee oor die oordeel, die opstanding van die dooies en die komende heerlikheid nie en vry is van die geleerde en fantastiese spekulasie. Sy boodskap word gekonsentreer in die cen gedagte, naamlik dat God sal regeer.

Jesus verwys nie na die geskiedenis van mense as die sfeer waarbinne die oordeel, met gevolglike straf of beloning, sal plaasvind nie. Bultmann meen dat vir Jesus die oordeel geheel en al gekonsentreer is in die eindoordeel waar almal rekenskap sal gee van hulle werke. Hy spreek die mense hieroor aan, maar op so 'n manier dat Hy hulle 
roep om Hom te volg. Sy prediking verskil van die apokaliptiek daarin dat Hy nie enigsins 'n beeld gee van die komende heil nie, behalwe om te sê dat dit lewe is en dat die dooies uit die dood opgewek sal word tot hierdie lewe. Simbolies beeld Hy die heil uit as 'n groot feesmaal, maar dit is duidelik dat die kwaliteit van lewe nie 'n aardse een sal wees nie, maar soos dié van die engele in die hemel (Bultmann1975:33). Die veroordeeldes se lot is egter 'n vlammende hel (Bultmann 1980:4).

Vir Bultmann bestaan daar nie twyfel oor die feit dat Jesus die oortuiging gehad het dat die koninkryk van God naby gekom het en dat die tyd van hierdie wêreld uitgeloop het nie. Die koms van die Seun van die Mens as regter en verlosser, die opstanding en die oordeel is voorhande. Hoewel daar wel sekere tekens van die tye is, kan die tyd van die koms van die koninkryk nie bereken word nie. Hyself is egter die eintlike teken; sy teenwoordigheid, dade en boodskap. Dit beteken egter nie dat die koninkryk alreeds aangebreek het nie, maar dat dit naby is en dat mense daarop moet voorberei deur 'n beslissing ten opsigte van Jesus te maak. Volgens Bultmann het hierdie beslissing by die sinoptici, anders as by Johannes, nie te make met geloof in sy persoon nie en het Jesus Homself nie as Messias voorgehou nie. Hy praat ook van die Seun van die Mens as iemand anders as Hyself. Jesus verpersoonlik self die eis tot 'n beslissing, en sy oproep tot bekering is God se laaste woord voor die einde (Bultmann 1956:87-93; 1980:5-10).

Bultmann verstaan Jesus se verwagting van die nabye einde van die wêreld as 'n vergissing (Bultmann 1956: 92). Die vraag is egter of die betekenis van sy boodskap saam met hierdie vergissing moet staan of val. Hy meen egter dat die proposisie omgekeer moet word deur te stel dat Jesus se verwagting van die nabye einde van die wêreld verbonde is aan die grondgedagte van sy prediking, naamlik die wil en beheer van God. Dit sou meebring dat Jesus sterk onder die indruk hiervan, Homself moes beskou het as op die grens van die tyd. Sy eskatologiese prediking ontstaan nie uit ' $n$ verlange na of spekulasie oor die einde nie, maar uit sy oortuiging van die nietigheid van die mens voor God, en die oordeel van God oor die wêreld.

Alhoewel Jesus se dissipels en die vroegste kerk die gevolgetrekking uit sy verkondiging gemaak het dat Hy die verwagte Messias was, of die komende Seun van die Mens sou wees, is Bultmann, soos ons gesien het, daarvan oortuig dat Jesus Homself nie as die Seun van die Mens beskou het nie (Bultmann 1980:27-34). Dit is die algemene siening dat hierdie gevolgtrekking van die sinoptici en die vroeë kerk in Jesus se. bewuswees van Homself as Messias of Seun van die Mens gegrond was. Veral danksy histories-kritiese eksegese is hierdie siening volgens Bultmann baie problematies. Gemeet aan die tradisionele Messiaanse verwagtings was Jesus se lewe en werk nie Messiaans nie, en Bultmann wys daarop dat geen Jesus-woord aangehaal kan word 
waar Hy van Homself as die komende Seun van die Mens praat nie. Tog stel Bultmann dit duidelik dat die erkenning dat Jesus die Een is deur wie God die mens beslissend ontmoet, 'n geloofsdaad is, onafhanklik van watter titel aan Hom toegeken word en of Jesus Homself as Messias of Menseseun beskou het of nie.

\subsection{Die eskatologie van die vroegste kerk}

Jesus was vir die vroegste kerk meer as net leermeester en profeet; Hy was ook Messias, en anders as by Jesus se eie prediking, het Hy nou self in die vroeë kerk die inhoud van die prediking geword. Er, früher der Träger der Botschaft, ist jetzt selbst in die Botschaft einbezogen worden; ist ihr wesentlicher Inhalt. Aus dem Verkundiger ist der Verkundigte geworden - aber in welchem Sinne? Das ist die entscheidende Frage! (Bultmann 1980:35). Sy antwoord op hierdie beslissende vraag is dat Jesus spesifiek as die komende Messias, as Seun van die Mens, verkondig is. Dit beteken dat nie sy wederkoms as Messias verwag is nie, maar sy aankoms (Ankunfi) as Messias. Sy aardse optrede van die verlede is nie deur die vroeë kerk beskou as Messiaanse optrede nie. Die verkondiging van Jesus as Messias of Menseseun plaas die eskatologie van die vroegste kerk binne die raamwerk van die eskatologiese verwagting van die na-eksiliese Israeliete. Die mitiese figuur van die Messias het egter konkreet sigbaar geword deurdat God Jesus van Nasaret, die leermeester en profeet wat deur die Romeine gekruisig is, tot Messias gemaak het en Hom verhoog het tot Seun van die Mens wat weer op die wolke sal kom. Deurdat die mite oorgedra is na 'n konkrete historiese persoon, is die vertroue daarin onmeetbaar versterk. Hy is steeds (soos in sy eie verkondiging) deur die vroee kerk beskou as die verkondiger van die radikale eis van God (Bultmann 1980: 36).

Die vroeë kerk het Jesus se eskatologiese prediking voortgesit en dit verryk deur temas vanuit die Joodse apokaliptiek oor te neem. Dit is 'n boodskap oor die komende einde van die wêreld binne die onmiddellike toekoms. Hierdie verwagting word gehandhaaf te midde van twyfel daaroor. Temas vanuit die Ou Testament word ook gekombineer met die apokaliptiese eskatologie. So verstaan die vroeë kerk sigself as die 'Israel van God', die 'uitverkore volk', 'God se eie volk' en die 'twaalf stamme in die verstrooiing'. Abraham word beskou as die vader van al die gelowiges. Die Christelike gemeenskap se selfverstaan is dié van die doel en die voltrekking van die geskiedenis te wees. Daar word teruggekyk op die geskiedenis van Israel, met die siening dat die doel met daardie geskiedenis nou bereik is. Dit beteken egter nie volgens Bultmann (1975:35-36) dat die vroeë kerk enigsins verstaan is as 'n ware fenomeen van die geskiedenis nie, of dat die verhouding met die volk Israel as 'n werklike historiese kontinuiteit gesien is nie. Daar is geen genealogiese verbintenis tussen die nuwe volk van 
God en die oue nie, en indien daar enige sou wees, is dit irrelevant. Abraham is die vader van alle gelowiges, uit die heidendom en Israel. Die kontinuiteit is nie ' $n$ historiese een nie, maar 'n kontinuiteit wat deur God daargestel word. God het 'n nuwe volk geroep om God se volk te word. Vir hierdie nuwe volk sal al die beloftes van die Ou Testament vervul word, omdat dit uit die staanspoor juis beloftes vir hierdie volk was. Die Ou Testament is in die eerste plek gelees as 'n boek van beloftes en openbarings wat nou vervul is, eerder as 'n historiese boek. Vir die eerste keer is dit moontlik om die betekenis van Israel se geskiedenis en die woorde van die Ou Testament te verstaan, omdat die Goddelike raadsplan wat tot nog toe verborge was, openbaar gemaak is. Dit bestaan nie daarin dat Israel se geskiedenis op Goddelike wyse gestuur word, soos wat die Deuteronomistiese geskiedskrywing dit weergee, naamlik dat die geregtigheid van God geken kan word deur die wisseling van gebeure in die geskiedenis nie. Die inhoud van die Goddelike raadsplan is die eskatologiese gebeure wat met aie inkarnasie van Christus begin plaasvind het, met sy kruisiging, opstanding en verheerliking, en wat voortgaan in die bekering van die heidene en die daarstelling van die kerk as die liggaam van Christus. Al hierdie dinge sal tot 'n einde kom met die verwagte laaste dinge.

Die Nuwe Verbond is nie gebaseer op 'n gebeure in die geskiedenis soos met die Ou Verbond nie, omdat die dood van Christus waarop dit gegrond is, nie volgens Bultmann 'n historiese gebeurtenis is waarop 'n mens kan terugkyk op dieselfde wyse as met die Moses-gebeure nie. Die rede hiervoor is dat Bultmann reken dat die nuwe volk van God geen geskiedenis het nie, omdat dit 'n gemeenskap van die eindtyd is, 'n eskatologiese gebeure (vgl ook Bultmann 1956:175-176; 1980:39-44). Dit kan nie 'n geskiedenis hề nie, omdat die wêreldtyd verby is, en die einde voorhande is. Die bewussyn van eskatologiese gemeenskap te wees, het die verdere bewussyn van uit hierdie wêreld geneem te wees. Die wêreld word gesien as die sfeer van onreinheid en sonde, ' $n$ vreemde land omdat die Christene se burgerskap 'n hemelse een is. Daarom het die Christene ook nie 'n verantwoordelikheid teenoor hierdie wêreld en die orde daarvan nie, maar moet hulle hulle juis rein hou van hierdie wêreld. Die etiek is negatief ingestel, naamlik een van onthouding en heiliging. In hierdie sin bly die Ou-Testamentiese wette van $\mathrm{krag}$, tesame met verdere verordening uit die Stoïsynse filosofie. Selfs die liefdesgebod funksioneer op 'n negatiewe manier in soverre dit onselfsugtigheid vereis, maar nie konkrete doelwitte daarstel vir optrede nie. Die asketiese ideaal begin hier en daar vroeg reeds in die Christelike etiek binnedring. Die feit dat die verwagte koms van Christus nie plaasgevind het nie, het teleurstelling en twyfel tot gevolg gehad. Die vermanings en waarskuwings om waaksaam te bly, het derhalwe vermeerder. Antwoord moes gegee word op die vraag waar die vervulling van die belofte van 
sy koms dan is. Die antwoord was dat God anders as mense met tye reken, asof een dag vir Hom soos duisend jaar is en duisend jaar soos een dag (2 Pet 3:8). Sulke antwoorde sou egter nie vir lank 'n oplossing vir die probleem bied nie (Bultmann 1975: 36-37).

\subsection{Die eskatologie van die Hellenistiese kerk}

Die sendingprediking aan die heidense wêreld kon nie bloot eskatologiese prediking wees nie, maar moes begin met die verkondiging van die een ware God wat aan die heidendom, gekenmerk deur veelgodedom en afgodery, onbekend was. Hierdie prediking was deur die sending aan Israel beïnvloed. Die Israeliete se Godsbegrip is in hierdie proses telkens aangepas en weer deur die godsbegrip in die Griekse filosofiese tradisie beinvloed. Dit is 'n godsbegrip wat bepaal word deur 'n kosmologies georiënteerde wet en orde wat sterk gebaseer was op die Stoïsyne se godsbewyse en die goddelike voorsienigheid in die natuur en teodisee. God se eise is nou, anders as in die Ou Testament, voorgehou as 'n morele wet en dit is gekoppel aan die begrip 'deug' asook aan 'n hele sisteem van deugde, die idee van onderrig en die metodes van onderwys. Al hierdie tendense is in die Christelike sendingprediking aan die heidene opgeneem met spesifiek Christelike aanpassings daarvan (Bultmann 1980:67-68).

Die basiese elemente van die sendingprediking kan soos volg saamgevat word: Die heidense wêreld word beskryf as vervalle in onkunde en dwaling; derhalwe word die aanvaarding van die Christelike boodskap beskryf as kennis van God of kennis van die waarheid. Hierdie aanvaarding word geloof genoem. God word nie alleen beskryf as Skepper nie, maar ook as die groot Wetgewer, en daarom tegelyk as Regter wat oor die mensdom sal oordeel in terme van God se wet. Soos in Israelitiese kringe, word in die Christelike verknndiging 'n duidelike verband gelê tussen sonde en die heidense veelgodedom en afgodery, en word die heidense leefwyse beskryf as 'n sondige lewe. Gevolglik word die oproep tot geloof in die een ware God tegelyk geformuleer as 'n oproep tot bekering. Die Christelike prediking rakende die een ware God is tegelyk ook eskatologiese prediking. Hiermee word bedoel dat die spoedig naderende oordeel oor die wêreld sterk aandag kry (Bultmann 1980:75-76). Hoewel daar ooreenkomste is met die Joodse apokaliptiek, lê die verskil in die nabyheid van die komende oordeel en die verbintenis van die persoon van Jesus aan die oordeel of bevryding daarvan. Onlosmaaklik verbonde aan die prediking met betrekking tot die komende oordeel, is die verkondiging van die opstanding van die dooies omdat die dooies ook verantwoording sal moet doen vir hulle dade. Om die opstanding van die dooies te ontken, word beskou as ontkenning van die oordeel self. Die Christologiese motief word sodoende in die kerugma met betrekking tot die oordeel opgeneem, omdat Jesus Christus beskryf word as 
aan God se sy of in die plek van God as Regter oor die wêreld, as God se gevolmagtigde en tegelyk ook as Verlosser van die gelowiges.

\subsection{Die eskatologie by Paulus}

Volgens Bultmann (1975:38-40) het die problematiek rondom die eskatologie begin met die uitbly van die wederkoms. Dit het by Paulus die gevolg gehad dat die eskatologie gehistoriseer is! Paulus se verstaan van die geskiedenis word dan ook bepaal deur sy eskatologiese siening. Wanneer Paulus terugkyk op die geskiedenis van Israel, sien hy dit nie as die geskiedenis van 'n volk se opstandigheid, sonde, straf, berou en vergifnis nie, maar as die geskiedenis van die hele mensdom wat sedert Adam vasgevang is in die mag van die sonde. Daar is vir hom wel 'n eenheid in die geskiedenis, naamlik die eenheid van die sonde. Dit beteken dat die ganse mensdom, Israeliete en heidene voor God skuldig staan en onder God se oordeel is. Om hierdie rede kan die einde van die geskiedenis nie die natuurlike gevolg wees van historiese gebeure nie, maar sal dit die afbreek van die geskiedenis wees wat deur God self teweeggebring word. Die doel van die geskiedenis is egter wel die einde daarvan, aangesien die genade van God die einde bring wanneer die mag van die sonde kragtig geword het. In hierdie sin het die geskiedenis betekenis, alhoewel dit nie uit optrede en gebeure in die geskiedenis afgelei kan word nie.

Dit is vir Bultmann (1975:41-42) duidelik dat hierdie siening van Paulus nie gegrond is in die geskiedenis van Israel soos dit in die Ou Testament berig word nie, maar wel in die apokaliptiek. Die apokaliptiese siening is egter op 'n deurslaggewende wyse deur Paulus gewysig in die sin dat hy die apokaliptiese siening interpreteer in terme van sy eie antropologie. Paulus se siening van die geskiedenis is gebaseer op sy siening van die mens: mense kan lewe alleen ontvang deur die genade van God, maar kan hierdie genade alleen ontvang as hulle hulleself erken as mense wat voor God as veroordeeldes staan. Die mag van die sonde waarin mense hulle bevind, is die vooronderstelling vir die ontvangs van die genade. Volgens Bultmann is dit belangrik om raak te sien dat Paulus se begrip van die eskatologiese heil ook dié van die apokaliptiek is wat weer eens deur sy eie antropologie gewysig is. Verseker verwerp hy nie die apokaliptiese beeld van die toekoms, die paroesie, die opstanding van die dooies, die laaste oordeel en die glorie van die vrygespreektes nie. Die eintlike heil is die geregtigheid, en daarmee saam die vryheid. Die heerskappy van God is vir Bultmann geregtigheid en vrede en vreugde. Daarby is die heil wat bedoel is vir die enkeling, 'n heil wat reeds in die hede teenwoordig is. Wie gedoop is, is reeds in Christus, en net so is die mens wat in Christus is, ' $n$ nuwe mens; die oue is verby en die nuwe het gekom. Die Gees van God is aan die gelowiges gegee, en hulle is nou reeds kinders van God. 
Hierdie belewenis van die heil in die hede het vir Bultmann daarmee te make dat alle mense in elke nuwe situasie gekonfronteer word met besluite wat hulle moet neem. Vir Paulus is die oproep van die hede 'n roep van God na die mens. Vir Paulus is mense nie vry van hulle verlede om vir God te kan kies nie. Mense wil maar eintlik bly soos wat hulle is. In essensie is dit die wese van die sonde. Christelike eksistensie beteken daarenteen ' $n$ lewe van vryheid om wel te kan kies; 'n vryheid wat deur die genade van God in Jesus Christus aan mense geskenk is.

Mense wat geregverdig is, is van hulle verlede bevry en so ook van hulleself en van die sonde, en is bevry tot ' $n$ lewe van vrye besluitneming (Bultmann 1975:44-45).

\subsection{Die eskatologie by Johannes}

Die benadering tot die eskatologiese gebeure as iets wat reeds in die hede plaasvind, word nog meer radikaal deur Johannes deurgevoer, aangesien die vierde evangelis die verwagting van die paroesie as kosmiese katastrofe in die toekoms laat vaar (Bultmann 1960:89). Vir Johannes is die opstanding van die dooies en die laaste oordeel reeds teenwoordig in die koms van Jesus na die wêreld. Auferstehung und Parusie Jesu sind für Johannes identisch (Bultmann 1980:410). Dit beteken dat daar nie 'n tweede koms verwag word nie, omdat die paroesie reeds plaasgevind het. Ook die koms van die Heilige Gees word nie as afsonderlike gebeure gesien nie. Pase, pinkster en paroesie is by Johannes een en dieselfde gebeure. Dit is juis as die Gees dat Christus na sy gemeente kom, en dit gebeur in die Woordverkondiging (Bultmann 1980:437, 442).

Vir Johannes het die gelowige reeds die oordeel van God verbygegaan, terwyl die ongelowige beskou word as een wat reeds veroordeel is. Die gelowige is een wat reeds uit die dood opgestaan het. Soos vir Paulus, is die lewe van die gelowige vir Johannes nie 'n statiese toestand nie, maar 'n dinamiese beweging tussen die dialektiek van die indikatief en die imperatief. Gelowiges moet steeds word wat hulle reeds is. Johannes beskryf die dialektiek van die Christelike bestaan met betrekking tot ' $n$ vraagstelling wat nog nie by Paulus gefunksioneer het nie, naamilik die dialektiek tussen die vryheid van die sonde, die noodsaaklikheid van die konstante belydenis van skuld en konstante vergifnis. Johannes kyk natuurlik ook soos Paulus vooruit na 'n toekomstige vervolmaking van die huidige lewe, maar nie soos Paulus in die sin van 'n apokaliptiese eskatologie met 'n verwagting van 'n kosmiese katastrofe nie. Johannes kyk eerder vooruit na die toekoms van die individuele gelowiges aan die einde van hulle aardse lewens. Hy gee 'n nuwe interpretasie van die paroesie van Christus. Volgens Johannes beloof Christus aan sy dissipels dat Hy weer sal terugkeer en hulle na Hom sal neem, na die Vaderhuis waar daar baie woonplek is (Bultmann 1975:41-49). 
Vir beide Paulus en Johannes is die hede ' $n$ tyd tussen-in. Vir Paulus: tussen die opstanding en paroesie van Christus aan die einde van die wêreld; vir Johannes: tussen die verheerliking van Christus met sy kruisiging en die einde van die aardse lewe van die individuele sondaar. Vir beide van hulle het hierdie tussen-in tyd nie net kronologiese betekenis nie maar essensiële betekenis, naamlik dié van die dialektiek tussen die alreeds en die nog nie (Bultmann 1975:49).

\subsection{Die eskatologie van die antieke kerk}

Bultmann (1975:49-55; 1980:513) is daarvan oortuig dat hierdie betekenis van die tyd tussen-in, en daarmee saam die Pauliniese e.l Johannese verstaan van die verhouding tussen geskiedenis en eskatologie, nie net so kon voortbestaan nie. Alhoewel hierdie verstaan nie volledig in die post-Pauliniese literatuur verdwyn het nie, het dit later tog wel verdwyn, en het die tyd tussen-in gewoon kronologiese tyd geword. Verlossing beteken nou slegs die vergifnis van sonde wat met die doop ontvang word en wat aar die gelowige ' $n$ nuwe begin bied. Gelowiges moet nou self die voorwarde nakom vir hulle regverdiging in die komende oordeel. Daarmee word mense weer aan hulleself en hulle eie kragte corgelaat en ontstaan 'n strewe na perfeksie met aan die een kant die ideaal van heiligmaking en aan die ander kant wettiese moralisme.

Van deurslaggewende belang vir hierdie studie van Bultmann se verstaan van die eskatologie, soos toegepas op 2 Petrus, is die vraag na hoe die antieke kerk die verhouding tussen geskiedenis en eskatologie verstaan het, of te wel hoe die ontwikkelende kerk die teleurstelling oor die uitbly van die wederkoms oorkom het. Bultmann dui aan dat hierdie teleurstelling nie skielik gekom het nie, maar geleidelik en ook nie oral op dieselfde tyd nie. Die wederkoms was nooit op 'n vasgestelde dag verwag nie, maar op die dag wat God vasgestel het en wat aan niemand bekend was nie. In die lig hiervan is die twyfel en teleurstelling wat hier en daar opgevlam het, stilgemaak en het die Christene geleidelik daaraan gewoond geraak om te wag op die wederkoms. Dit is wel so dat die nabye wederkomsverwagting in tye van vervolging weer opgevlam het. Tog wys die Pastorale Briewe daarop dat Christene geleidelik 'n leefwyse aangeneem het van tegelyk burgerlik en Christelik was. Die eskatologie is egter nooit laat vaar nie. Die verwagte einde van die wêreld is maar net verskuif in die onbepaalde toekoms. Dit het plaasgevind sonder enige groot skok, nie net omdat die Christene gewoond geraak het aan die wag nie, maar ook as gevolg van die ontwikkeling van sakramentalisme. Daar was twee gevolge van die sakramentalisme: een was dat dit die belang van gelowiges laat weg verskuif het van die universele eskatologie, na die verlossing van die individu, naamlik in die sin van 'n geseènde onsterflikheid wat deur die sakrament gewaarborg word. Die ander gevolg was dat die mag van God wat 'n einde aan die wê- 
reld sal bring, alreeds aan die werk is en wel in die sakramente wat deur die kerk bedien word (Bultmann 1975:51-52). Die gevolg was verder dat kerk in die Hellenistiese wêreld nou die karakter van 'n kultiese gemeenskap gekry het, en dat die eskatologiese Messias of Seun van die Mens al hoe meer vervang is met die figuur van die Kurios, die Here wat in die kultus teenwoordig is. Die heil is dan in 'n sekere sin aanwesig in die teenwoordigheid van die Here, maar nie soos by Paulus en Johannes in die eskatologiese eksistensie van die gelowiges nie. Christus is primêr in die sakramente teenwoordig. Dit beteken nie dat die eskatologie in die sakramentele kerk verwerp is nie, maar in der waarheid geneutraliseer is. Belangstelling in die eskatologie neem af en om een of ander rede word die kosmiese drama nou beskou asof dit alreeds plaasgevind het in die koms en vertrek van die hemelse Redder. Gelowiges sien die kerk nou as die gevolg van die kosmiese oorwinning van Christus, dit wil sê as eskatologiese fenomeen (Bultmann 1975:51-54).

Alhoewel die heil ook as toekomstig gesien is, beteken dit nie 'n terugkeer na die ou apokaliptiese eskatologie nie. Aber der traditionelle Bild der urchristlichen Eschatologie ist so gut wie ganz verschwunden (Butmann 1980:541). Die hoop word gerig op die heil van die enkeling. Sommige van die ou apokaliptiese beelde is egter behou, soos die gedagte aan die eindoordeel. Die koms van die Verlosser is nie meer die eskatologiese koms nie, maar die inkom van Jesus in die geskiedenis. Die kosmiese katastrofe wat in die apokaliptiek verwag is, het reeds plaasgevind in Jesus se geboorte, dood en opstanding. Buiten die toekomstige heil, is die heil ook in die hede 'n werklikheid. So is Christus die lewe van die gelowige en is om in Christus te wees, die lewe. Saam met die individuele piëteit, is daar ook sprake van ekklesiastiese piëteit: die heil is aan die enkeling beskikbaar in die kerk, in besonder deur die sakramente (Bultmann 1980:542-543).

2.11 Die plek van die begrip 'dag van die Here' in 2 Petrus teen die agtergrond van die ontwikkeling van die eskatologie.

Die bespreking van die plek van 2 Petrus teen die agtergrond van die ontwikkeling van die eskatologie kom by Bultmann (1980:66-93) tereg in sy uiteensetting van die eskatologie binne die Hellenistiese kerk buite Paulus om.

Hy dui aan hoedat die verkondiging van die imminente oordeel al die geskrifte van die Nuwe Testament deursuur, behalwe by Johannes se geskrifte waar daar 'n besondere interpretasie daarvan is. Vir Bultmann is dit aanduiding daarvan dat die tradisionele siening van die geweldige eskatologiese drama deel was van die struktuur van Christelike denke. Die gedeeltes van die Nuwe Testament waar Bultmann dit raaksien, is in die Pauliniese en Deutero-Pauliniese literatuur, Handelinge, Hebreërs, 
Jakobus, en dan veral in kragtige beelde in Openbaringe en 2 Petrus. Hierdie oortuiging word op verskeie plekke in die Nuwe Testament in dieselfde terme beskryf, naamlik God as Regter wat op 'n spesifieke dag sal kom om te oordeel. In 2 Petrus 3:7

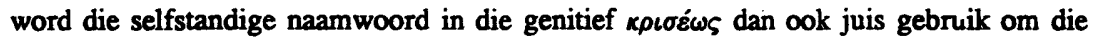
besondere dag te kwalifiseer as 'n dag van oordeel. Verskeie Nuwe-Testamentiese tekste pas die Ou-Testamentiese term dag van die Here toe op hierdie dag van oordeel, en daar is heelwat waarskuwings om gereed en waaksaam te bly met die oog op die koms van die dag van die Here. Die koms van die dag van die Here word in 2 Petrus 3:10 beskryf as so onverwags as ' $n$ dief in die nag en in 2 Petrus 3:4 word dit in verband gebring met die paroesie van Christus (Bultmann 1980:78-79).

Wat die eskatologie betref, was die selfbeskouing van die vroeë kerk volgens Bultmann (1975:37) dié van 'n eskatologiese fenomeen en nie 'n historiese fenomeen nie. In die vroeë Christendom is die geskiedenis deur die eskatologie verswelg. Die kerk was bewus daarvan dat hulle nie meer tot die huidige wêreld behoort nie, maar tot die toekomstige aeon wat voor die deur sou wees. Die vraag sou wees hoe lank hierdie bewussyn lewend kon bly, hoe lank die verwagting van die imminente einde van die wêreld nog standvastig kon bly voortduur.

Uiteraard het die feit dat die verwagte wederkoms van Christus nie plaasgevind het nie, aanleiding gegee tot teleurstelling en twyfel. Daarom het die waarskuwings om waaksaam te bly ook vermeerder. Die stryd teen hierdie twyfel het baie belangrik geword. Hierdie twyfel is, soos reeds hierbo vermeld, verwoord in 2 Petrus 3:4 waar gevra word wat van die belofte van die wederkoms geword het omdat, sedert die dood van die vaders, alles nog net so bly soos dit was van die begin van die skepping af. Die antwoord is dat God met ander tye reken as mense en dat vir die Here een dag soos duisend jaar, en duisend jaar soos een dag is. Hierdie antwoord sou egter nie vir lank bevredig nie (Bultmann 1975:37). Dit is in hierdie bepaalde historiese fase in die ontwikkeling van die Nuwe-Testamentiese eskatologie, naamlik twyfel oor die uitbly van die wederkoms, dat Bultmann 2 Petrus, en spesifiek die term dag van die Here, plaas.

\section{ONTMTTOLOGISERING EN EKSISTENSIALE INTERPRETASIE}

In sy heel cerste opstel oor die Nuwe Testament en mitologie stel Bultmann (1967:18) dit onomwonde dat die mitiese eskatologie tot die verlede hoort, aangesien Christus se wederkoms nie plaasgevind het nie. Die mite behoort nie in kosmologiese terme geinterpreteer te word nie, maar in antropologiese terme (Bultmann1967:22). Hoe dit gedoen word. het hy gedemonstreer met die opstel, 'Die christliche Hoffnung und das Problem der Entmythologisierung' (Bultmann 1960:81-90). 
Wanneer daar in 2 Petrus na die dag van die Here verwys word, het ons te make met 'n uitdrukking van die Christelike hoop op die koms van die Verlosser wat op verskillende maniere in die Nuwe Testament beskryf word. Bultmann (1960:82) wys op twee belangrike aspekte in verband met hierdie verwagting: Die eerste is naamlik dat die komende aanbreek van die einde van die wêreld deur die vroegste Christendom as in die nabye toekoms verwag is. Met die uitbly van hierdie gebeure het die hoop vervaag of twyfel ingetree, waarvan 'n aantal vermaninge hieroor in die Nuwe Testament gevind word. Hierdie vraagstelling bereik wat die Nuwe Testament betref, 'n hoogtepunt in 2 Petrus. Die hoop op die wederkoms word steeds nie prysgegee nie, maar slegs die verwagting dat dit in die nabye toekoms sal gebeur.

Die tweede aspek waarop Bultmann wys, is die feit dat hierdie verwagting met betrekking tot die einde van die wêreld nie 'n spesifiek Christelike verwagting is nie, maar vanuit die Joodse apokaliptiek en die gnostiek van die Hellenistiese heidendom oorgeneem is. Uit die Joodse apokaliptiek is daar kleurryke beskrywings van die dag van die Here en die Messias se koms, of te wel die koms van die Seun van die Mens as die hemelse Regter en Verlosser. Hierdie verwagting is deur die Christendom oorgeneem, in die sin dat daar in die plek van die koms van God nou die koms van Christus verwag is wat tegelyk die gevolmagtigde Seun van die Mens is (Bultmann 1960:82).

Uit die Hellenisties-heidense gnostiek is 'n totaal andersoortige verwagting oorgeneem, naamlik dié van die ondergang van hierdie wêreld en die verlossing van siele daaruit na die wêreld van die lig. Die gelowiges en vromes staan uit die dood op om saam met die skare hemelinge die Heer van die wêreld van die lig te prys. Vir Bultmann (1960:83) is daar nie aan te twyfel nie dat beide hierdie verwagtings mitologies van aard is, wat elk aan 'n bepaalde mitologiese wêreldbeeld verbonde was.

Met die beskrywing van die dag van die Here in 2 Petrus het ons myns insiens waarskynlik te make met ' $n$ vermenging van beide die Joodse apokaliptiese verwagting sowel as die Hellenisties-heidense verwagtings. Daar is sprake van die dag van die Here, 'n apokaliptiese begrip uit die Ou Testament. Die vernietiging van hierdie wêreld word op 'n prentjie-agtige manier beskryf, en 'n nuwe hemel en aarde word verwag. Volgens Bultmann is hierdie mitologiese voorstellings vir die modeme mens wie se lewe deur die wetenskap bepaal word, vreemd en behoort dit ontmitologiseer te word ten einde die Intention des Mythos te bepaal (Bultmann 1960:84).

Een van die grondmotiewe vir die ou verwagting van die vroegste Christene is die mens se onvergenoegdheid met die hier en nou wat nie aan die mens ware lewensvervulling kan skenk nie. Dit is daarom tegelyk die erkenning dat ware lewensvervulling alleen te vinde is in 'n Werklikheid wat hierdie wêreld transendeer. Es ist damit zugleich das Wissen darum, daß sein eigentliches Wesen die Welt transzendiert, in der er 
lebt, aber die er als sein Arbeitsgebiet verfügt, und in der er seine Schicksal hat .... (Bultmann 1960:88). Hierdie verwagtings beskou die vervulling van die mens ce lewe nie as iets wat deur die mens se planne of optrede bewerk word nie, maar alleen as 'n Geschenk won jenseits, Geschenk der Grade Gottes (Bultmann 1960:88).

Wanneer 'n mens enigsins iets oor God wil sê, is dit tegelyk altyd 'n uitspraak oor die mens self (Bultmann 1958b:28). Die manier waarop daar oor die transendensie van God gepraat word, is analogies aan die kategoriee waarbinne die mens bestaan, naamlik in terme van ruimte en tyd.

Net soos wat daar in die beskouing oor die hemel cor die transendensie van God in ruimtelike terme gepraat word, net so word daar in die beskouing oor die einde van die wêreld oor die transendensie van God gepraat in terme van tyd (Buitmann 1958a:22). Hoewel die mitologiese spreekwyse moontlik as naiewe spreke beskou kan word, bly dit 'n poging om in die kleure van hierdie wêreld iets oor die transendente te skilder. Hat man die Verdiesseitigung des Jenseitigen als charakteristische des mythologischen Vorstellens erkannt und leistet man entschloßen Verzicht auf sie, so ist die eigentliche Intention des mythologischen Hoffnungsbilde nicht schwer zu erkennen (Bultmann 1960: 88-89). Dit kom neer op 'n bestaan in die hede wat op 'n besondere manier deur die toekoms bepaal word, naamlik dat die God van die hede tegelyk ook die komende God is. Dit is ' $n$ bestaan wat bepaal word deur of die verlede, of die toekoms: mense sterf of saam met hulle verlede of lewe vanuit hulle toekoms. Ware lewe is lewe wat oop is vir die toekoms. Hierdie betekenis is volgens Bultmann (1956:186) verberg en van volle realisering versper deur die Joods-apokaliptiese beelde oor die kosmiese einddrama wat die kerk van na-eksiliese Israel oorgeneem het.

Die mitologiese spreke van 'n eskatologiese begrip soos die dag van die Here in 2 Petrus kan steeds vir gelowiges in die moderne tyd besondere betekenis hê: Der Gott der Gegenwart ist immer der kommende Gott; und gerade nur indem er das ist, ist er der Gott der Gegenwart, dessen Gnade den Menschen won der Gebundenheit an seine Vergangenheit befreit und für die Zukunft - für Gottes Zukunft - offnet (Bultmann 1960:90; my beldemtoning). God is volgens Bultmann in terme van hierdie eskatologiese spreekwyse die God van die hede omdat God ook God van die toekoms is.

Met hierdie erkenning is tegelyk die waarde en eie reg van hierdie mitologiese spreke -ingesien, aangesien dit aan die individu die oorwinning oor die dood beloof. Bultmann (1960:90) verduidelik die saak so: Die enigste sekerheid van die menslike toekoms is immers die sekerheid oor die dood wat kom. Vir hulle wat oop is vir elke soort toekoms as die toekoms van die komende God, het die verskrikking van die dood kragteloos geword. Sulke mense erken dat die mitologiese beelde oor 'n heerlikheid na die dood alleen wensbeelde van die fantasie is (analogiese taal?), en sien daarvan af om 
sulke beelde te skilder. Hierdie afsien van die skilder van mitologiese fantasiebeelde beteken ' $n$ radikale oopwees vir God se toekoms, naamlik as die vervulling van die mens se lewe.

\begin{abstract}
Er wird darauf verzichten, die Zukunft, die Gott im Tode schenkt, auszumalen; denn alle Bilder von einer Herrlichkeit nach dem Tode können nur Wunschbilder der Phantasie sein; und der Verzicht auf Wunschbilder gehört zur radikalen Offenheit des Glaubens an Gottes Zukunft. Der durch die Entmythologisierung freigelegte Sinn der mythologischen Hoffnungsbilder aber ist der, daß sie von der Zukunft Gottes reden als von der Erfüllung des menschlichen Lebens.
\end{abstract}

(Bultmann 1960:90)

Bultmann (1958a:30-33) beskryf hierdie toekoms wat op die gelowiges anderkant die dood en hierdie wêreld wag, as 'n toekoms van die totale nuwe, die totaliter aliter wat uitgedruk word met verwysing na ' $n$ nuwe hemel en ' $n$ nuwe aarde (2 Pet 3:13). Vir hierdie nuwe toekoms wat God daarstel, moet die gelowiges om twee redes gereed wees: omdat dit kom wanneer ons dit nie verwag nie (so onverwags soos 'n dief in die nag), en omdat hierdie toekoms 'n oordeel sal wees oor almal wat hulle aan hierdie wêreld verbind het en daarom nie vry is en oop is vir God se toekoms nie. In eksistensiale terme gestel, is die gelowiges wat oop is vir God se toekoms, die mense wat outentiek lewe (eigentlich existieren) (Bultmann 1965a:130). Die Christelike gemeenskap kan uit die staanspoor beskryf word as gemeenskap wat radikaal oop is vir God se toekoms, omdat hulle hulleself beskou het as gemeenskap van die eindtyd wat op die punt was om aan te breek, en omdat hulle deur God eenkant uit hierdie wêreld gestel is. Eerder as 'n historiese fenomeen, kan die kerk derhalwe beskryf word as eskatologiese fenomeen. Hoe langer die wederkoms uitgebly het, hoe moeiliker het dit egter geword om as eskatologiese gemeenskap te lewe. Teleurstelling en twyfel het gegroei, waarvan argumente van die spotters in 2 Petrus voorbeelde is (vgl 2 Pet 3:4) (Bultmann 1975: 35-37). Die brief self is myns insiens 'n poging om in die lig van die uitbly van die wederkoms steeds eskatologiese eksistensie as outentieke eksistensie voor te hou.

As daar na die historiese konteks van 2 Petrus vanuit die moderne wêreldbeeld teruggekyk word, sou daar gesê kon word dat die outeur aan die lesers duidelik wou maak dat hulle hulle lewens deur God se toekoms moet laat bepaal, en nie deur hierdie wêreld nie. Ware lewensvervulling lê nie in die dinge van hierdie wêreld, soos wat die dwaalleraars te kenne wou gee nie, maar in God se toekoms. Alhoewel hierdie toe- 
koms nie duidelik omskryf is nie, word daar nie corgegaan tot 'n kleurvolle skildering daarvan nie, maar slegs gemeld dat dit 'n nuwe hemel en aarde sal wees waar die wil van God sal heers. Wie nie hieraan vashou nie, soos die dwaalleraars en die spotters, is nie oop vir God se toekoms nie en is ook nie in staat om ware lewensvervulling te smaak nie. Die regverdigheid van God is hierin geleë. Die klem is in 2 Petrus juis op die sekerheid van die Goddelike oordeel. Die gelowige kan daarvan oortuig wees, en sodoende bevry word van 'n soeke na lewensvervulling in hierdie wêreld wat tot vernietiging gedoem is. Hierdie bevryding is egter nie vir die spotters beskore nie.

\section{Literatuurverwysings}

Bultmann, R K [1933] 1958. Glauben und Verstehen: Gesammelte Aufsatze, I. 3.Aufl. Tübingen: Mohr.

1965. Glauben und Verstehen: Gesammelte Aufsazze, IV. Tübingen: Mohr. 1956. Primitive Christianity in its contemporary setting. Philadelphia: Fortress.

- 1958a. Jesus Christ and mythology. New York: Charles Scribner's Press. 1958b. Welchen Sinn hat es von Gott zu reden?, in Bultmann [1933] 1958: 26-37.

1960. Die christliche Hoffnung und das Problem der Entmythologisierung, in Bultmann [1933] 1958:81-90.

1965a. Zum Problem der Entmythologisierung, in Bultmann 1965:128-137.

1967a. Neues Testament und Mythologie: Das Problem der Entmythologisierung der neutestamentlichen Verkündigung, in Bartsch, $\mathrm{H}-\mathrm{W}$ (Hrsg), Kerygma' und Mythos, I: Ein theologisches Gespräch, 15-48. Hamburg-Bergstedt: Herbert Reich Evangelischer Verlag. (ThF1.)

1975. History and eschatology: The Gifford lectures. Edinburgh: Edinburgh University Press.

1980. Theologie des Neuen Testaments. Tübingen: Mohr.

Elliott J H 1982. James, 1-2 Peter, Jude. Minneapolis: Augsburg. (Augsburg Commentary on the New Testament.)

Malan, G J \& Van Aarde, A G 1998. 'n Kennissosiologiese benadering tot die dag van die Here in 2 Petrus. HTS, 54/3 \& 4, 529. 